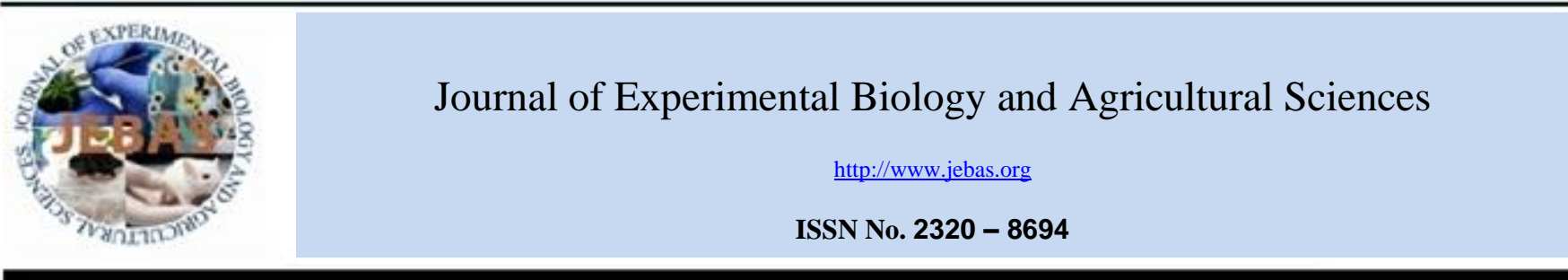

\title{
DIVERSITY, DISTRIBUTION AND ABUNDANCE OF LICHEN IN SIMILIPAL BIOSPHERE RESERVE, ODISHA
}

\author{
Srimay Pradhan ${ }^{1}$, Dalip Kumar Upreti ${ }^{2}$, Kunja Bihari Satapathy ${ }^{1 *}$ \\ ${ }^{1}$ Department of Botany, School of Applied Sciences, Centurion University of Technology and Management, Odisha, India \\ ${ }^{2}$ Lichenology Laboratory, CSIR-National Botanical Research Institute, Lucknow, India
}

Received - August 12, 2021; Revision - November 22, 2021; Accepted - December 05, 2021

Available Online - December 30, 2021

DOI: http://dx.doi.org/10.18006/2021.9(6).781.790

\section{KEYWORDS \\ Lichenized fungi \\ Diversity \\ Similipal Biosphere Reserve \\ Mayurbhanj \\ Odisha}

\begin{abstract}
Lichens are organized symbionts that have their importance due to a potential indicator of the forest ecosystem. The lichen diversity of Odisha is not well explored as compared to the other phytogeographical region of India. Though the earlier study reported the occurrence of 252 lichen species from different parts of the state, it was limited to the northeast part of the Similipal Biosphere Reserve (SBR). The objective of the present study was to survey some unexplored areas of SBR, which revealed the occurrence of 84 species of lichens belonging to 38 families and 18 genera. Most of the lichens were found growing as phorophytes on the matured bark of the trees. The western part of the SBR is rich in lichen diversity as compared to the eastern part. Species frequency was found to be highest in the southwest part of the SBR, while the density and abundance were more or less similar within all the study sites. The correlation between frequency and density was found to be significant and insignificant between frequency and abundance.
\end{abstract}

* Corresponding author

E-mail: kbs_bot@rediffmail.com (Kunja Bihari Satapathy)

Peer review under responsibility of Journal of Experimental Biology and Agricultural Sciences.

Production and Hosting by Horizon Publisher India [HPI] (http://www.horizonpublisherindia.in/).

All rights reserved.
All the articles published by Journal of Experimental Biology and Agricultural Sciences are licensed under a Creative Commons Attribution-NonCommercial 4.0 International License Based on a work at www.jebas.org.

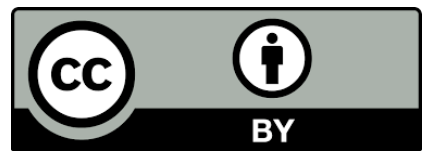




\section{Introduction}

Lichens are the example of the symbiotic association between one fungus (ascomycetes or basidiomycetes) and one alga or cyanobacterium leading to the formation of self-sustaining life forms. The fungal hyphae absorb the required nutrients from the substratum while the algal cells synthesize food through photosynthesis (Weerakoon \& Aptroot, 2016). The world lichen biota is represented by more than 20,000 species (Galloway, 2008) out of which 2714 species are reported from India (Sinha et al., 2018). Indian phytogeographical regions have been divided into 8 categories (Figure 1), among which Eastern Himalayas recorded for 1286 species which is highest as compared to other phytogeographic regions (Shukla et al., 2014). Odisha is coming under central India and the Eastern Ghats. However, the diversityrelated to lichen of Odisha is scantily available. According to the work compiled by Nayak et al. (2016), the lichen flora of Odisha is represented by 252 species belonging to 81 genera under 35 families. The study of lichen diversity has been done in different districts of Odisha including Jharsuguda (Upreti, 1996; Das et al., 2018), Khurdha (Satapathy et al., 2016; Pradhan et al., 2020), Kendrapara (Panda et al., 2017), Gajapati (Swarnalatha, 2017), Puri (Nayak et al., 2017; Majhi \& Pradhan, 2020), Jajpur (Nayak et al., 2018), Angul (Mishra et al., 2020) and Dhenkanal (Nayak et al., 2015). Mayurbhanj is the largest district of Odisha according to the land area, mostly covered with the forest canopy. The Similipal Biosphere Reserve covers almost half of the geographical area of the Mayurbhanj district and is spread over an area of $5569 \mathrm{~km}^{2}$, which comprises dense forested hills and valleys with dry deciduous vegetation (Pradhan et al., 2021). On average, the area receives $1800 \mathrm{~mm}$ annual rainfall with a temperature variation of a minimum of $3^{\circ} \mathrm{C}$ to a maximum of $38^{\circ} \mathrm{C}$ during winter and summer respectively. The areas near streams with low elevation have trees such as Syzygium cumini, Pongamia pinnata, Diospyros peregrina, Saraca asoca, and Terminalia arjuna. The elevated and moist areas are covered with Bombax ceiba, Alstonia scholaris, Madhuca indica, and Dalbergia sissoo. However, Shorea robusta was observed to be the dominant tree species in both lowlands and tiny hillocks. The earlier report indicated the occurrence of 141 species from the northwest part of the Similipal Biosphere Reserve (Singh \& Kamal, 2012; Sahoo \& Pradhan, 2020; Pradhan \& Satapathy, 2020). The community forest area of Udala, which is situated outside of SBR reported the occurrence of 22 lichen species (Pradhan et al., 2018). In the present study, different unexplored localities of Similipal Biosphere Reserve have been surveyed for the determination of their lichen diversity.

\section{Materials and Methods}

\subsection{Study area}

Similipal Biosphere Reserve lies between $21^{\circ} 28^{\prime}$ and $22^{\circ} 08^{\prime} \mathrm{N}$ latitudes and $86^{\circ} 04^{\prime}$ to $86^{\circ} 37^{\prime} \mathrm{E}$ longitudes in Mayurbhanj district of Odisha. Brundeiposi, Kaliani, Talabandh, Devkund, and Karkatbeda area of Similipal Biosphere Reserve were systematically surveyed and samplings were done (Figure 2).

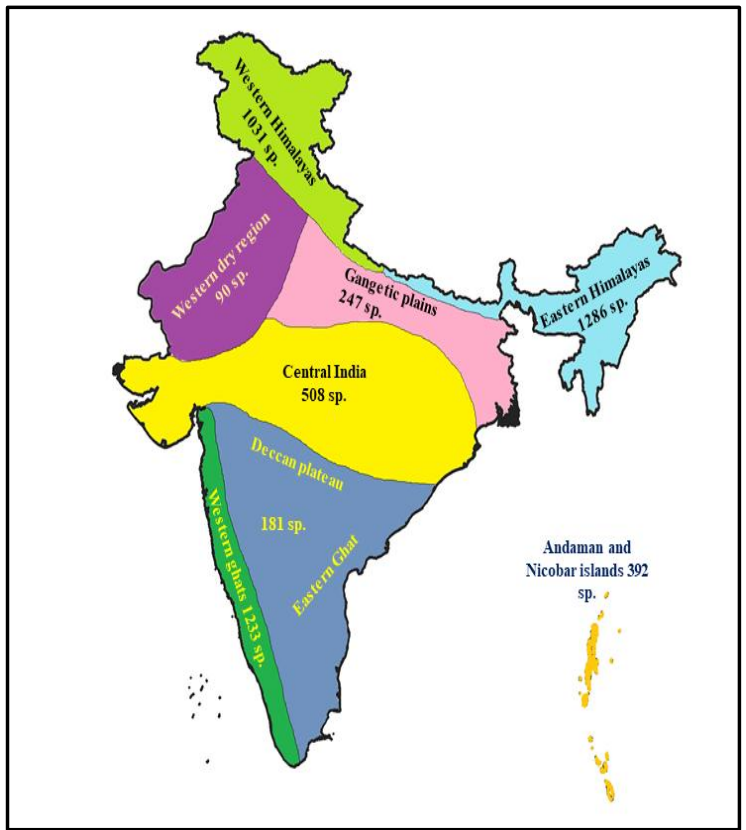

Figure 1 Number of lichen species recorded from different phytogeographical regions of India

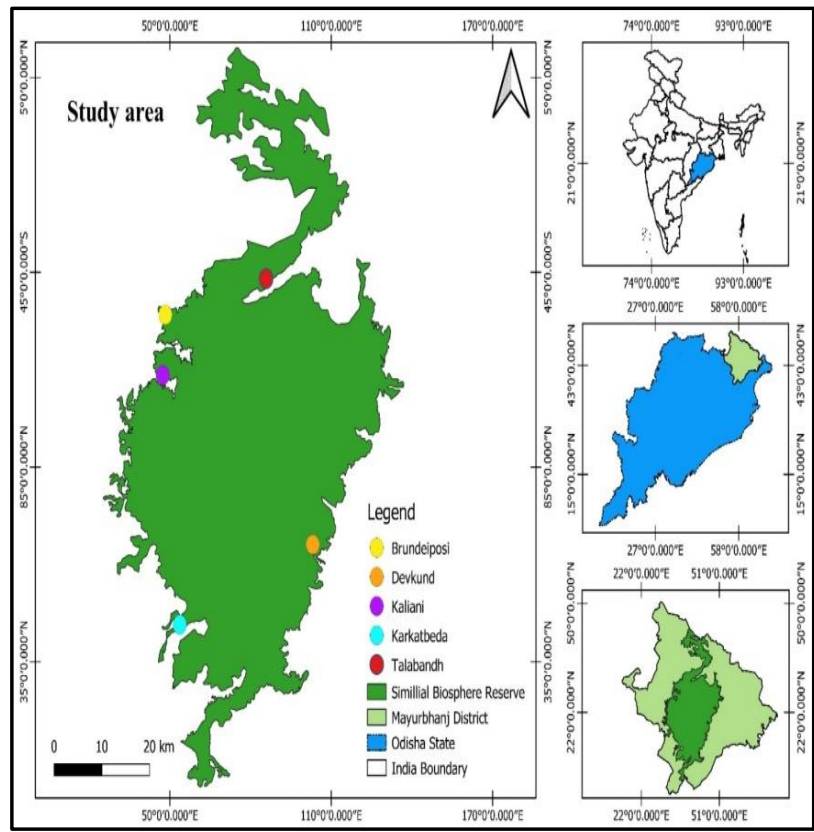

Figure 2 Map with survey sites situated within the Similipal Biosphere Reserve 
Table1 Lichen diversity of Similipal Biosphere Reserve (SBR) in Mayurbhanj district of Odisha

\begin{tabular}{|c|c|c|c|c|c|c|c|c|c|}
\hline \multirow{2}{*}{$\begin{array}{l}\text { Sl. } \\
\text { No. }\end{array}$} & \multirow{2}{*}{ Lichen taxa } & \multirow{2}{*}{ G.F. } & \multirow{2}{*}{ S } & \multicolumn{5}{|c|}{ Survey Sites } & \multirow{2}{*}{$\begin{array}{c}\text { Herbarium } \\
\text { (LWG) }\end{array}$} \\
\hline & & & & BS & $\mathrm{KN}$ & KD & $\mathrm{TD}$ & DK & \\
\hline \multicolumn{10}{|c|}{ Arthoniaceae } \\
\hline 1. & Arthothelium abnorme (Ach.) Müll. Arg. & $\mathrm{C}$ & $\mathrm{B}$ & - & - & - & + & - & 45332 \\
\hline 2. & Arthothelium confertum (A.L. Sm.) Makhija \& Patw. & $\mathrm{C}$ & B & - & + & - & - & - & 48622 \\
\hline 3. & Coniocarpon cinnabarinum DC & $\mathrm{C}$ & $\mathrm{B}$ & + & - & + & + & + & 45046 \\
\hline 4. & Cryptothecia effusa (Müll. Arg.) R. Sant. & $\mathrm{C}$ & $\mathrm{B}$ & + & + & - & - & - & 48589 \\
\hline 5. & Cryptothecia lunulata (Zahlbr.) Makhija \& Patw. & $\mathrm{C}$ & $\mathrm{B}$ & - & + & - & - & - & 45371 \\
\hline 6. & $\begin{array}{l}\text { Cryptothecia multipunctata Jagad. Ram, G.P. Sinha \& Kr.P. } \\
\text { Singh }\end{array}$ & $\mathrm{C}$ & $\mathrm{B}$ & - & + & + & - & - & 45316 \\
\hline 7. & Cryptothecia striata G.Thor & $\mathrm{C}$ & B & - & - & + & - & - & 45134 \\
\hline 8. & Cryptothecia subtecta Stirt. & $\mathrm{C}$ & $\mathrm{B}$ & + & + & - & - & - & 48587 \\
\hline 9. & Herpothallon isidiatum Jagad. Ram \& G.P. Sinha & $\mathrm{C}$ & $\mathrm{B}$ & + & + & + & - & - & 45203 \\
\hline 10. & Herpothallon philippinum (Vain.) Aptroot \& Lücking & $\mathrm{C}$ & B & + & + & + & - & - & 45208 \\
\hline \multicolumn{10}{|c|}{ Caliciaceae } \\
\hline 11. & Amandinea montana (H. Magn.) Marbach & $\mathrm{C}$ & $\mathrm{B}$ & + & + & - & - & - & 44953 \\
\hline 12. & Cratiria obscurior (Stirt.) Marbach \& Kalb & $\mathrm{C}$ & $\mathrm{R}$ & + & + & + & - & - & 45074 \\
\hline 13. & Dirinaria aegialita (Afzel. ex Ach.) B.J. Moore & $\mathrm{F}$ & B & + & + & + & + & - & 45069 \\
\hline 14. & Dirinaria applanata (Fée) D.D. Awasthi & $\mathrm{F}$ & B & - & + & - & + & - & 45140 \\
\hline 15. & Dirinaria consimilis (Stirt.) D.D. Awasthi & $\mathrm{F}$ & B & + & - & - & - & - & 45368 \\
\hline 16. & Pyxine coccifera (Fée) Nyl. & $\mathrm{F}$ & $\mathrm{B}$ & - & - & + & - & - & 45249 \\
\hline 17. & Pyxine cocois (Sw.) Nyl. & $\mathrm{F}$ & $\mathrm{B}$ & - & + & - & - & - & 45157 \\
\hline 18. & Pyxine consocians Vain. & $\mathrm{F}$ & $\mathrm{R}$ & + & - & - & - & - & 45248 \\
\hline 19. & Pyxine reticulata (Vain.) Vain. & $\mathrm{F}$ & B & - & + & + & - & - & 50078 \\
\hline \multicolumn{10}{|c|}{ Chrysotrichaceae } \\
\hline 20. & Chrysothrix candelaris (L.) J.R. Laundon & $\mathrm{C}$ & B & - & - & - & - & + & 45005 \\
\hline \multicolumn{10}{|c|}{ Collemataceae } \\
\hline 21. & Leptogium austroamericanum (Malme) C.W. Dodge & $\mathrm{F}$ & $\mathrm{B}$ & - & - & - & + & - & 45336 \\
\hline \multicolumn{10}{|c|}{ Graphidaceae } \\
\hline 22. & Diorygma hieroglyphicum (Pers.) Staiger \& Kalb & $\mathrm{C}$ & B & + & + & + & - & - & 45182 \\
\hline 23. & Diorygma junghuhnii (Mont. \& Bosch) Kalb, Staiger \& Elix & $\mathrm{C}$ & $\mathrm{B}$ & + & + & + & + & - & 45177 \\
\hline 24. & $\begin{array}{c}\text { Diorygma rufosporum (Patw. \& C.R. Kulk.) B.O. Sharma \& } \\
\text { Makhija }\end{array}$ & $\mathrm{C}$ & $\mathrm{B}$ & + & + & + & - & - & 45167 \\
\hline 25. & Diorygma soozanum (Zahlbr.) M. Nakan. \& Kashiw. & $\mathrm{C}$ & B & + & + & - & - & + & 45180 \\
\hline 26. & Dyplolabia afzelii (Ach.) A. Massal. & $\mathrm{C}$ & $\mathrm{B}$ & + & - & - & - & - & 44913 \\
\hline 27. & Fissurina comparimuralis Staiger & $\mathrm{C}$ & $\mathrm{B}$ & - & + & - & - & - & 48621 \\
\hline 28. & Glyphis cicatricosa Ach. & $\mathrm{C}$ & B & - & - & - & - & + & 44911 \\
\hline 29. & Graphis ajarekarii Patw. \& C.R. Kulk. & $\mathrm{C}$ & B & - & - & + & + & - & 48562 \\
\hline
\end{tabular}

Journal of Experimental Biology and Agricultural Sciences http://www.jebas.org 


\begin{tabular}{|c|c|c|c|c|c|c|c|c|c|}
\hline \multirow{2}{*}{$\begin{array}{l}\text { Sl. } \\
\text { No. }\end{array}$} & \multirow{2}{*}{ Lichen taxa } & \multirow{2}{*}{ G.F. } & \multirow{2}{*}{$S$} & \multicolumn{5}{|c|}{ Survey Sites } & \multirow{2}{*}{$\begin{array}{l}\text { Herbarium } \\
\text { (LWG) }\end{array}$} \\
\hline & & & & BS & $\mathrm{KN}$ & $\mathrm{KD}$ & TD & DK & \\
\hline 30. & Graphis albidofarinacea Adaw. \& Makhija & $\mathrm{C}$ & B & - & + & - & - & - & 45075 \\
\hline 31. & Graphis caesiella Vain. & $\mathrm{C}$ & B & + & - & - & - & - & 45387 \\
\hline 32. & Graphis capillacea Stirt. & $\mathrm{C}$ & B & - & + & - & - & - & 48566 \\
\hline 33. & Graphis chlorotica A. Massal. & $\mathrm{C}$ & B & - & - & + & - & - & 45315 \\
\hline 34. & Graphis elegans (Borrer ex Sm.) Ach. & $\mathrm{C}$ & B & - & - & + & - & - & 44964 \\
\hline 35. & Graphis furcata Fée & $\mathrm{C}$ & B & - & - & - & - & + & 48612 \\
\hline 36. & Graphis glaucescens Fée & $\mathrm{C}$ & B & - & + & - & - & - & 48618 \\
\hline 37. & Graphis lineola Ach. & $\mathrm{C}$ & B & - & - & + & - & - & 50083 \\
\hline 38. & Graphis proserpens Vain. & $\mathrm{C}$ & B & - & - & - & + & - & 48613 \\
\hline 39. & Graphis scripta (L.) Ach. & $\mathrm{C}$ & B & - & + & + & - & - & 45011 \\
\hline 40. & Phaeographis endophaeiza (Stirt.) Zahlbr. & $\mathrm{C}$ & B & + & + & + & + & + & 45033 \\
\hline 41. & Sarcographa labyrinthica (Ach.) Müll. Arg. & $\mathrm{C}$ & B & - & - & + & - & - & 44912 \\
\hline \multicolumn{10}{|c|}{ Haematommataceae } \\
\hline 42. & Haematomma puniceum (Ach.) A. Massal. & $\mathrm{C}$ & B & - & + & - & - & - & 45130 \\
\hline \multicolumn{10}{|c|}{ Lecanoraceae } \\
\hline 43. & Lecanora achroa Nyl. & $\mathrm{C}$ & B & + & + & + & - & + & 44914 \\
\hline 44. & Lecanora helva Stizenb. & $\mathrm{C}$ & B & - & + & + & - & - & 44947 \\
\hline 45. & Lecanora interjecta Müll. Arg. & $\mathrm{C}$ & B & - & - & - & + & - & 48629 \\
\hline 46. & Lecanora perplexa Brodo & $\mathrm{C}$ & B & + & + & + & + & - & 48582 \\
\hline 47. & Lecanora tropica Zahlbr. & $\mathrm{C}$ & B & - & + & - & - & - & 44951 \\
\hline 48. & Lecidella enteroleucella (Nyl.) Hertel & $\mathrm{C}$ & $\mathrm{R}$ & + & + & - & + & + & 45231 \\
\hline \multicolumn{10}{|c|}{ Letrouitiaceae } \\
\hline 49. & Letrouitia leprolyta (Nyl.) Hafellner & $\mathrm{C}$ & B & - & + & + & - & - & 44943 \\
\hline 50. & Letrouitia transgressa (Malme) Hafellner \& Bellem. & $\mathrm{C}$ & B & + & + & + & + & + & 45262 \\
\hline \multicolumn{10}{|c|}{ Parmeliaceae } \\
\hline 51. & Bulbothrix isidiza (Nyl.) Hale & $\mathrm{F}$ & B & + & + & + & + & - & 45050 \\
\hline 52. & Parmotrema praesorediosum (Nyl.) Hale & $\mathrm{F}$ & $\mathrm{R}$ & + & + & + & + & - & 45084 \\
\hline 53. & Parmotrema reticulatum (Taylor) M. Choisy & $\mathrm{F}$ & B & + & - & - & - & - & 45191 \\
\hline 54. & Parmotrema saccatilobum (Taylor) Hale & $\mathrm{F}$ & B & + & + & + & - & - & 45338 \\
\hline 55. & Parmotrema tinctorum (Despr. ex Nyl.) Hale & $\mathrm{F}$ & B & + & + & + & - & + & 45103 \\
\hline \multicolumn{10}{|c|}{ Pertusariaceae } \\
\hline 56. & Lepra leucosora (Nyl.) Hafellner & $\mathrm{C}$ & B & - & + & - & - & - & 45152 \\
\hline 57. & Pertusaria cinchonae Müll. Arg. & $\mathrm{C}$ & B & + & - & + & - & - & 48554 \\
\hline 58. & Pertusaria concinna Erichsen & $\mathrm{C}$ & B & + & - & - & - & - & 45281 \\
\hline 59. & Pertusaria indica Preeti Srivast. \& D.D. Awasthi & C & B & - & - & - & + & - & 48554 \\
\hline
\end{tabular}




\begin{tabular}{|c|c|c|c|c|c|c|c|c|c|}
\hline \multirow{2}{*}{$\begin{array}{l}\text { Sl. } \\
\text { No. }\end{array}$} & \multirow{2}{*}{ Lichen taxa } & \multirow{2}{*}{ G.F. } & \multirow{2}{*}{$S$} & \multicolumn{5}{|c|}{ Survey Sites } & \multirow{2}{*}{$\begin{array}{l}\text { Herbarium } \\
\text { (LWG) }\end{array}$} \\
\hline & & & & BS & $\mathrm{KN}$ & $\mathrm{KD}$ & $\mathrm{TD}$ & DK & \\
\hline 60. & Pertusaria leioplacella Nyl. & $\mathrm{C}$ & B & - & + & - & - & - & 45399 \\
\hline 61. & Pertusaria leucostoma (Ach.) A. Massal. & $\mathrm{C}$ & B & + & + & + & + & + & 48552 \\
\hline 62. & Pertusaria punctata Nyl. & $\mathrm{C}$ & B & - & + & + & - & - & 45396 \\
\hline 63. & Pertusaria quassiae (Fée) Nyl. & $\mathrm{C}$ & $\mathrm{B}$ & + & + & - & - & - & 45290 \\
\hline \multicolumn{10}{|c|}{ Petulaceae } \\
\hline 64. & Peltula euploca (Ach.) Poelt & $\mathrm{C}$ & $\mathrm{R}$ & + & - & - & - & - & 45339 \\
\hline \multicolumn{10}{|c|}{ Physciaceae } \\
\hline 65. & Heterodermia diademata (Taylor) D.D. Awasthi & $\mathrm{F}$ & $\mathrm{B}$ & - & + & - & - & - & 45078 \\
\hline 66. & Heterodermia obscurata (Nyl.) Trevis. & $\mathrm{F}$ & $\mathrm{B}$ & + & - & - & - & - & 45125 \\
\hline 67. & Heterodermia speciosa (Wulfen) Trevis. & $\mathrm{F}$ & B & - & + & - & - & - & 45077 \\
\hline 68. & Physcia caesia (Hoffm.) Fürnr. & $\mathrm{F}$ & B & + & + & - & - & - & 45016 \\
\hline 69. & Physcia sorediosa (Vain.) Lynge & $\mathrm{F}$ & $\mathrm{B}$ & - & + & + & - & - & 45322 \\
\hline 70. & Rinodina oxydata (A. Massal.) A. Massal. & $\mathrm{C}$ & $\mathrm{R}$ & - & + & - & - & + & 45337 \\
\hline \multicolumn{10}{|c|}{ Pyrenulaceae } \\
\hline 71. & Pyrenula leucotrypa (Nyl.) Upreti & $\mathrm{C}$ & $\mathrm{B}$ & + & - & - & - & - & 45019 \\
\hline 72. & Pyrenula nitida (Weigel) Ach. & $\mathrm{C}$ & B & - & - & + & - & - & 45347 \\
\hline \multicolumn{10}{|c|}{ Ramalinaceae } \\
\hline 73. & Bacidia alutacea (Kremp.) Zahlbr. & $\mathrm{C}$ & B & - & - & + & - & + & 44978 \\
\hline 74. & Bacidia convexula (Müll. Arg.) Zahlbr. & $\mathrm{C}$ & B & - & + & - & - & - & 48617 \\
\hline 75. & Bacidia millegrana (Taylor) Mill. Zahlbr. & $\mathrm{C}$ & B & + & - & - & - & - & 44983 \\
\hline 76. & Bacidia submedialis (Nyl.) Zahlbr & $\mathrm{C}$ & B & - & + & - & - & + & 44982 \\
\hline 77. & $\begin{array}{l}\text { Bacidina medialis (Tuck. ex Nyl.) Kistenich, Timdal, Bendiksby } \\
\text { \& S. Ekman }\end{array}$ & $\mathrm{C}$ & $\mathrm{B}$ & - & + & - & - & - & 48611 \\
\hline \multicolumn{10}{|c|}{ Ramboldiaceae } \\
\hline 78. & Ramboldia russula (Ach.) Kalb, Lumbsch \& Elix & $\mathrm{C}$ & B & + & - & - & - & - & 45333 \\
\hline \multicolumn{10}{|c|}{ Stereocaulaceae } \\
\hline 79. & Lepraria incana (L.) Ach. & $\mathrm{C}$ & $\mathrm{B}$ & + & - & - & - & - & 48631 \\
\hline \multicolumn{10}{|c|}{ Teloschistaceae } \\
\hline 80. & Caloplaca bassiae (Ach.) Zahlbr. & $\mathrm{C}$ & B & - & - & + & - & - & 45331 \\
\hline 81. & Caloplaca orissensis (Räsänen) D.D. Awasthi & $\mathrm{C}$ & $\mathrm{R}$ & - & - & - & - & + & 50057 \\
\hline \multicolumn{10}{|c|}{ Trypetheliaceae } \\
\hline 82. & Marcelaria benguelensis (Müll. Arg.) Aptroot, Nelsen \& Parnmen & $\mathrm{C}$ & B & + & + & + & - & - & 44905 \\
\hline 83. & Nigrovothelium tropicum (Ach.) Lucking, M.P. Nelsen \& Aptroot & $\mathrm{C}$ & $\mathrm{B}$ & + & + & + & - & + & 44904 \\
\hline 84. & Trypethelium eluteriae Spreng. & $\mathrm{C}$ & $\mathrm{B}$ & - & + & - & - & + & 44902 \\
\hline
\end{tabular}

BS - Brundeipoisi, KN - Kaliani, KD - Karkatbeda,TD - Talabandh, DK - Devkund; S- Substratum, B - Bark, R - Rock; G.F. - Growth form, C- Crustose, F - Foliose; + Present, - Absent 


\subsection{Methodology}

The survey was conducted during the period from July 2019 to June 2020. The sample plot was $10 \times 10 \mathrm{~m}^{2}$ according to the access of undulating terrain of the field condition. From each site, 10 quadrates plots were placed for the collection and documentation of lichen samples. The epiphytic and epilithic species were collected by using a chisel and hammer from the bark and rocks and documented properly for future reference. The samples were kept in polythene zipper bags and transported to the lab for analysis. The specimens were identified morphologically using a stereo-zoom microscope at $40 \mathrm{X}$ (Leica S8APO), anatomically under a compound microscope at $100 \mathrm{X}$ (Leica DM2500), and chemically following the available literature (Awasthi, 1991, 2000, 2007; Divakar \& Upreti, 2005; Joshi, 2008). Secondary metabolites were detected through thin layer chromatography (TLC) in solvent system C (Orange et al., 2001).

\subsection{Statistical analysis}

The statistical analysis for frequency, density, and abundance of species at different study sites was done by using MS-Excel (2010) and the correlation was done by PAST software. The calculation of frequency (\%) was carried out by the following formula (Sharma, 2005; Basistha et al., 2010).

Frequency $(F)=\frac{\text { Number of quadrats in which a species occurs }}{\text { Total number of quadrats sample }} \times 100$

The density and abundance were carried out by the following formulae:

Density (D) $=\frac{\text { Total number of individuals of a species in all quadrats }}{\text { Total number of quadrats studied }}$
Abundance $(A)=\frac{\text { Total number of individuals of a species in all quadrats }}{\text { Total number of quadrats in which species occured }}$

$$
\text { Jaccard's similarity index }\left(\mathrm{C}_{\mathrm{j}}\right)=\frac{\mathrm{a}}{\mathrm{a}+\mathrm{b}+\mathrm{c}}
$$

Where a - Number of species common to both sites, $\mathrm{b}$ - Number of species present in site B but not in A, c - Number of species present in site A but not in B.

\section{Results and Discussion}

A total of 84 species of lichens were found in the present study (Table 1) which belong to 38 genera and 18 families. The family Graphidaceae was found to be most dominant represented by 20 species followed by Arthoniaceaere presented by 10 numbers of species (Figure 3), which is similar to studies conducted in Western Ghats of India (Nayaka \& Upreti, 2005), Peru (Plata \& Lücking, 2013) and amazon rain forest of Brazil (Caceres et al., 2014). Based on genera, Graphis is found to be the most dominant followed by Pertusaria represented by 11 and 7 numbers of species respectively similar to the studies in northern Assam (Rout et al., 2010) and Mexico (Córdova-Chávez et al., 2014). Epiphytic species dominated the study area, growing on barks of matured as well as young trees represented by 77 numbers of species followed by epilithic species represented by only 7 numbers of species. The area was found to be dominated by a crustose form of lichens followed by foliose lichens which are represented by 66 and 18 numbers of species respectively. Based on growth form Kaliani $(\mathrm{KN})$ which is situated in the north-west region of the SBR, found to be enriched with both crustose and foliose lichens represented by 39 and 12 species respectively, while Devkund (DK) which is present in the south-east part of SBR registered the least diversity both for crustose and foliose forms represented by 16 and 1 species respectively (Figure 4).

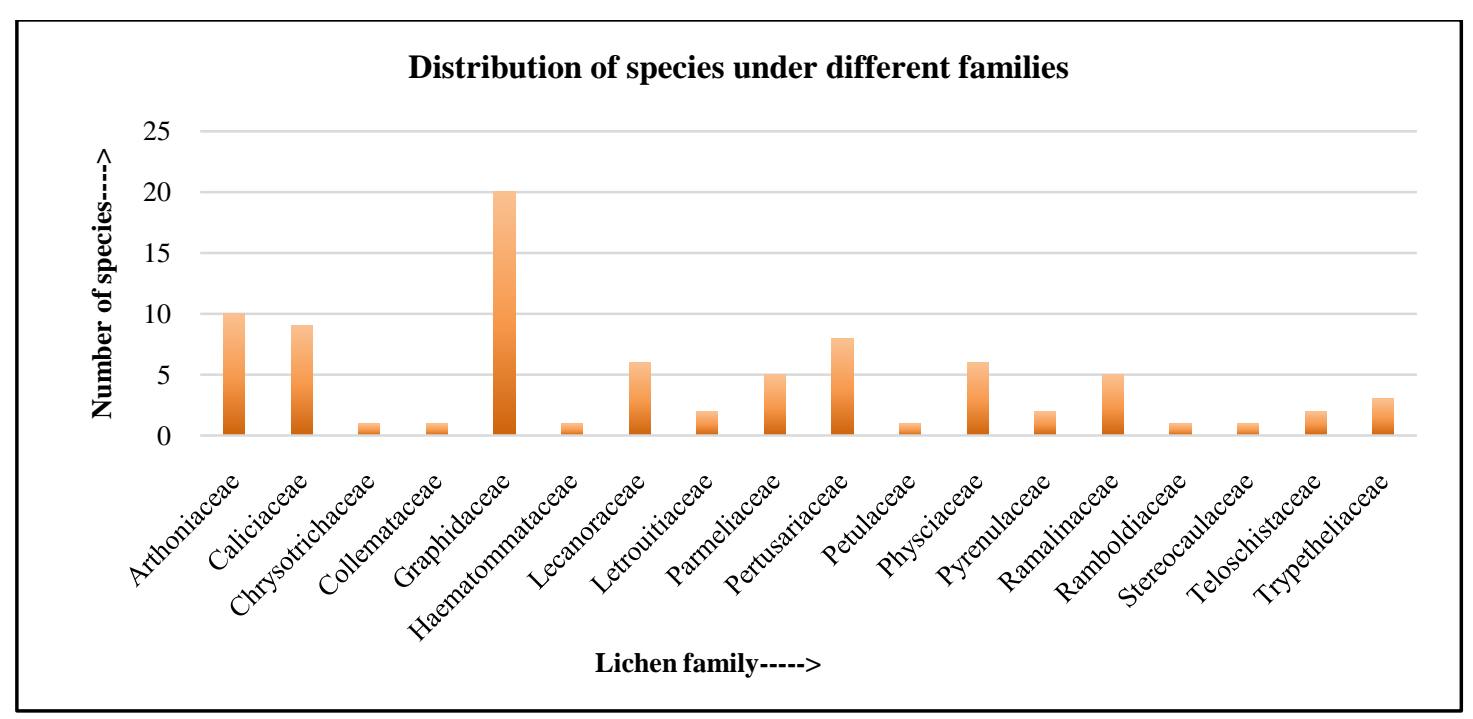

Figure 3 Lichen distributions under different families

Journal of Experimental Biology and Agricultural Sciences http://www.jebas.org 


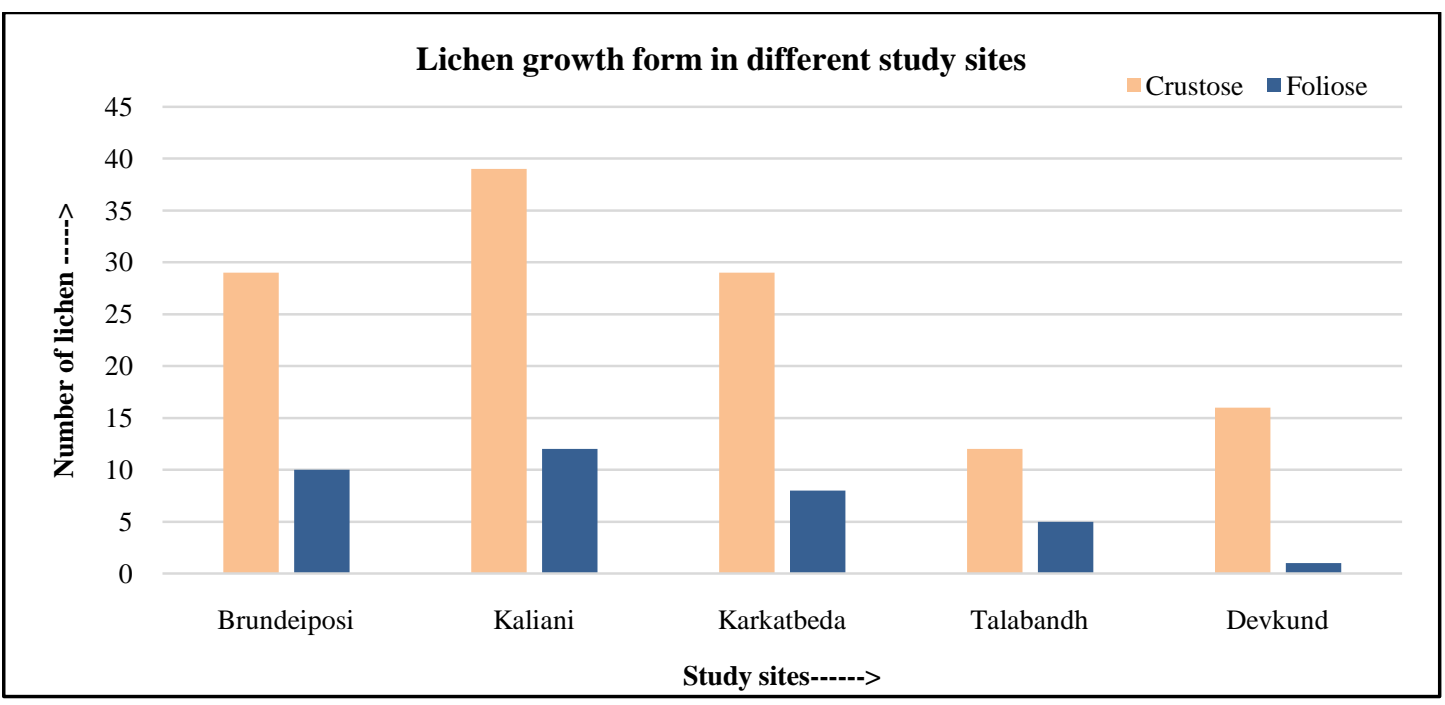

Figure 4 Growth of lichen forms in different study sites

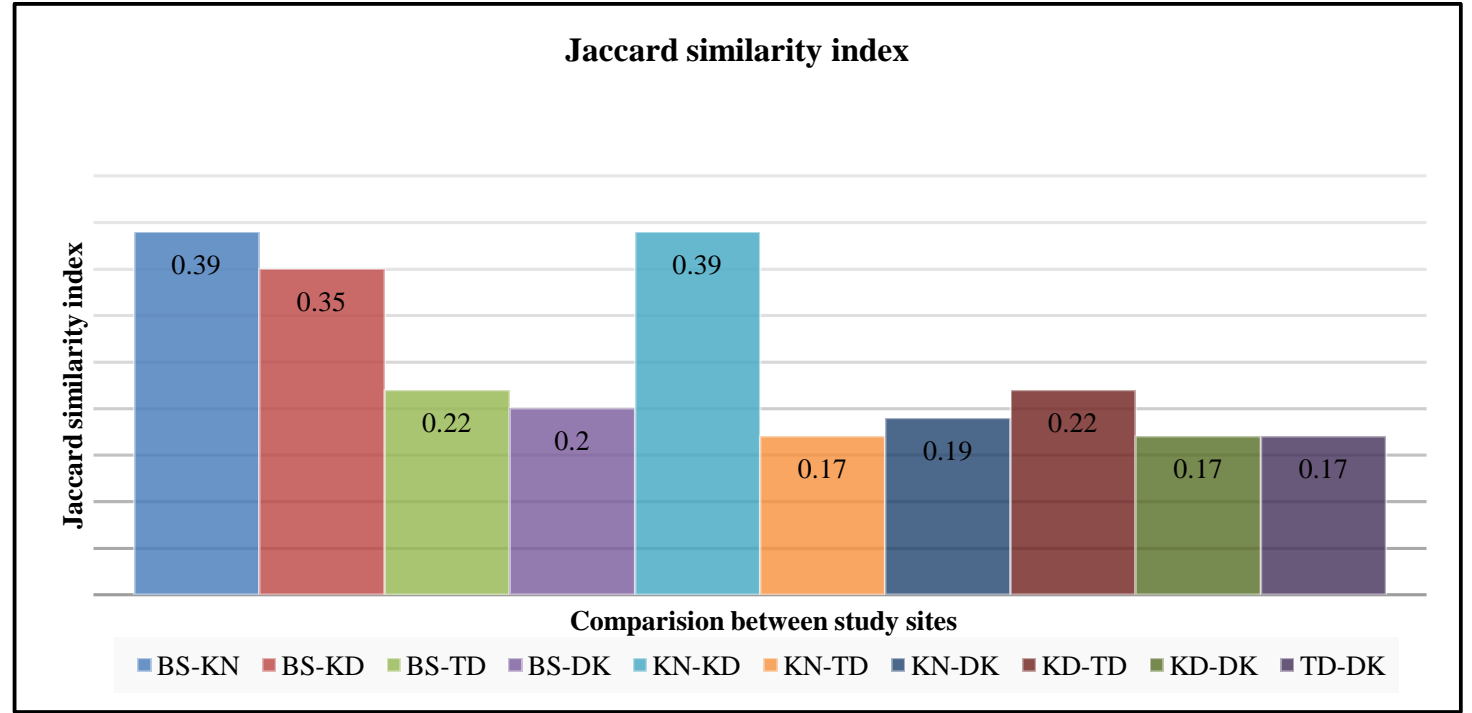

Figure 5 Jaccard's similarity index of recordedlichen species collected from different localities of Similipal Biosphere Reserve

The Jaccard's similarity index $\left(\mathrm{C}_{\mathrm{j}}\right)$ indicated that the study sites which are situated in the western part of SBR are more similar to each other's species distribution, as the similarity index was found to be 0.39 both for BS-KN and KN-KD (Figure 5). However, it $\left(\mathrm{C}_{\mathrm{j}}\right)$ was found least, similar between the study sites of KN-TD, KD-DK, and TD-DK. The values of the similarity index indicated that the western part of the SBR is having more or less similar species composition due to similar ecological structure (Mishra et al., 2008; Leinster \& Cobbold, 2012; Suárez-Mota et al., 2015; Oluyinka Christopher, 2020; Hidasi-Neto et al., 2020). The statistical analysis result shows the maximum frequency and density of lichens observed at Karkatbeda (KD) and least observed in Talabandh (TD) (Figure 6), which could be due to the dense forest canopy at the south-west part of the Similipal Biosphere Reserve as compared to the north-east, as suggested by the earlier studies (Pipp, 1998; Dymytrova et al., 2014; Wolseley et al., 2017). The density of lichens revealed a very minute difference in all the study sites selected, while abundance showed that the sites are more or less similar to each other. The diversity of lichen species is more in Brundeiposi, Kaliani, and Karkatbeda, as compared to Devkund and Talabandh, which can be correlated to the anthropogenic disturbances due to high tourist pressure in the eastern part of the Similipal Biosphere Reserve (Stevens, 1979; Shukla et al., 2014). The correlation between frequency and density was found to be significant, while it was insignificant between frequency and abundance at the level $\mathrm{p}>0.05$ (Figure 7). 


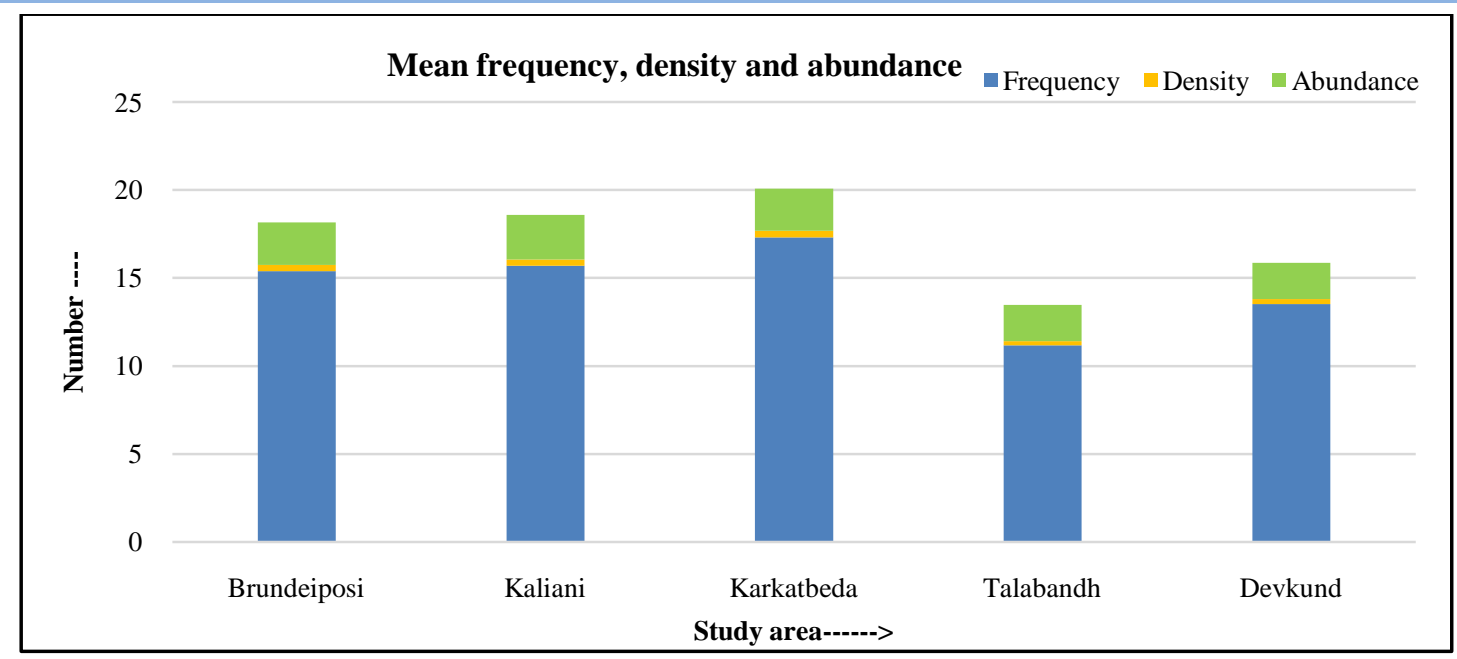

Figure 6 Species distribution pattern at different localities surveyed in Similipal Biosphere Reserve

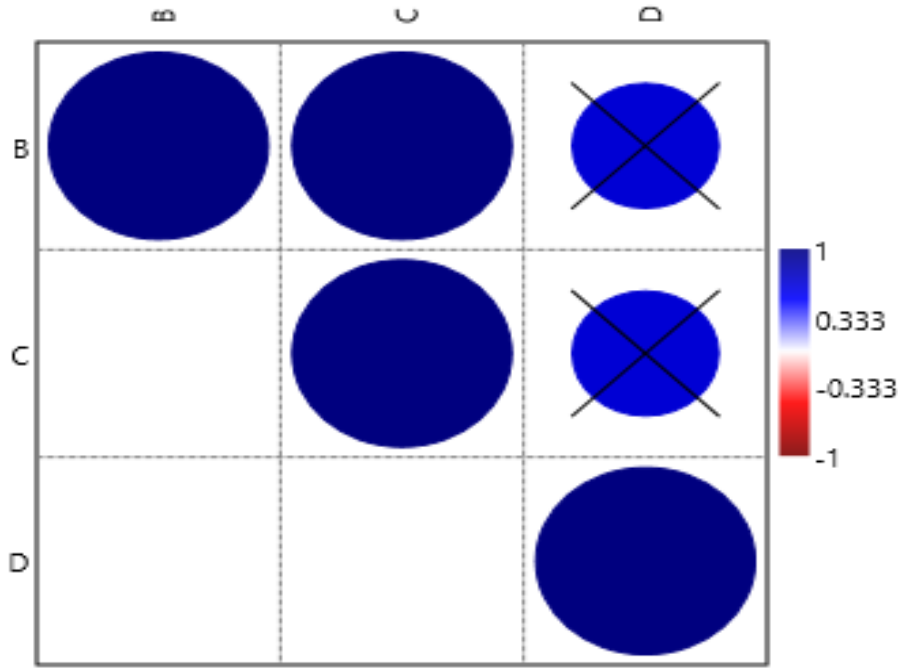

Figure 7 Correlation between frequency (B), density (C) and abundance (D) of lichen from different study sites

\section{Conclusion}

The present survey though revealed the lichen richness of the Similipal Biosphere Reserve, more intensive study in other unexplored areas will add a greater number of species to state and national biota.

\section{Acknowledgment}

The authors would like to thank and acknowledge their respective institution

\section{Conflict of interest}

All authors have read the Journal's policy on authorship agreement and disclosure of potential conflicts of interest. They have none to declare
Funding: No fund taken

\section{Authors' contributions}

SP had conceptualized the idea, worked and prepared the data and results along with the draft manuscript, DKU and KBS have edited the final draft manuscript. All authors have written, reviewed, and edited the manuscript.

\section{References}

Awasthi DD (1991) Key to the microlichens of India, Nepal and Sri Lanka. Bibliotheca Lichenologica 40:1-337.

Awasthi DD (2000) Lichenology in Indian subcontinent: A supplement to A hand book of lichens. Bishen Singh Mahendra Pal Singh, Dehradun.

Journal of Experimental Biology and Agricultural Sciences http://www.jebas.org 
Awasthi DD (2007) A Compendium of the Macrolichens from India, Nepal and Sri Lanka. Bishen Singh Mahendra Pal Singh, Dehradun.

Basistha BC, Sharma NP, Lepcha L, Arrawatia ML, Sen A (2010) Ecology of Hippophae salicifolia D.Don of temperate and subalpine forests of North Sikkim Himalayas - a case study. Symbiosis 50(1):87-95.

Caceres ME, Aptroot A, Parnmen S, Luecking R (2014) Remarkable diversity of the lichen family Graphidaceae in the Amazon rain forest of Rondônia, Brazil. Phytotaxa 189(1):87-136.

Córdova-Chávez O, Castillo-Campos G, Pérez-Pérez RE, GarcíaFranco JG, da Silva Cáceres ME (2016) Alpha diversity of lichens associated with Quercus laurina in a mountain cloud forest at Cofre de Perote eastern slope (La Cortadura), Veracruz, Mexico. Cryptogamie Mycologie 37(2):193-204.

Das K, Rossi W, Leonardi M, Ghosh A, Bera I, Hembrom ME, Bajpai R, Joseph S, Nayaka S, Upreti DK, Wang XH (2018) Fungal Biodiversity Profiles 61-70. Cryptogamie Mycologie 39(4):381-418.

Divakar PK, Upreti DK (2005) Parmelioid lichen in India (Reversionary studies). Bishan Singh Mahendar Pal Singh Publication, Dehradun.

Dymytrova L, Nadyeina O, Hobi ML, Scheidegger C (2014) Topographic and forest-stand variables determining epiphytic lichen diversity in the primeval beech forest in the Ukrainian Carpathians. Biodiversity and Conservation 23(6):1367-1394.

Galloway DJ (2008) Austral lichenology: 1690-2008. New Zealand Journal of Botany 46(4):433-521.

Hidasi-Neto J, Bini LM, Siqueira T, Cianciaruso MV (2020) Ecological similarity explains species abundance distribution of small mammal communities. Acta Oecologica102:103502.

Joshi Y (2008) Morphotaxonomic studies on lichen family Teloschistaceae from India. Unpublished Ph.D. thesis submitted to the Kumaun University, Nainital, Uttarakhand.

Leinster T, Cobbold CA (2012) Measuring diversity: the importance of species similarity. Ecology 93(3):477-489.

Majhi PP, Pradhan S (2020) Diversity and distribution of fructicose lichen in Puri district of Odisha, India. Indian Journal of Natural Sciences 10 (60): 26619-26624.

Mishra RK, Upadhyay VP, Mohanty RC (2008) Vegetation ecology of the Similipal Biosphere Reserve, Orissa, India. Applied Ecology and Environmental Research 6(2):89-99.
Mishra R, Chand PK, Satapathy KB (2020) Some new additions to the lichen flora of Odisha. Plant Archives 20: 1979-1986.

Nayak SK, Mohapatra A, Chand PK, Satapathy KB (2015) Diversity of lichen flora in Kapilash reserve forest of Dhenkanal district in Odisha, India. Abstract presented in National conference on cryptogam research in India: Progress and Prospects. Indian Lichenological Society, Lucknow.

Nayak SK, Bajpai R, Upreti DK, Satapathy KB (2016) Diversity of lichen flora of Odisha, India- A review. Studies in Fungi 1(1):11424.

Nayak SK, Behera PK, Bajpai R, Upreti DK, Satapathy KB (2017) Lichens growth on Sun Temple of Konark in Odisha, India-A curse or blessing. Cryptogam Biodiversity and Assessment 2(2): $48-52$

Nayak SK, Behera PK, Bajpai R, Satapathy KB, Upreti DK (2018) A Need for Lichen Bio-deterioration Study on Ratnagiri and Udayagiri Excavation Site of Jajpur, Odisha. Cryptogam Biodiversity and Assessment 3(1): 20-23.

Nayaka S, Upreti DK (2005) Status of lichen diversity in Western Ghats, India. Sahyadri E-News, Western Ghats Biodiverstity Information System 16:1-28.

Oluyinka Christopher A (2020) Comparative Analyses of Diversity and Similarity Indices of West Bank Forest and Block A Forest of the International Institute of Tropical Agriculture (IITA) Ibadan, Oyo State, Nigeria. International Journal of Forestry Research 2020:1-8. https://doi.org/10.1155/2020/4865845.

Orange A, James PW, White FJ (2001) Microchemical methods for the identification of lichens. British Lichen Society, England.

Panda M, Murthy TVR, Samal RN, Lele N, Patnaik AK, Mohan PK (2017) A comparative study of manglicolous lichens and their distribution inside Bhitarkanika National Park (Odisha), India. Studies in Fungi 2(1):1-13.

Pipp AK (1998) Effects of forest age versus forest structure on epiphytic lichen biomass and diversity. The University of Monatana, USA, Pp. 1-84

Plata ER, Lücking R (2013) High diversity of Graphidaceae (Lichenized Ascomycota: Ostropales) in Amazonian Perú. Fungal diversity 58(1):13-32.

Pradhan S, Behera PK, Nayak SK, Satapathy KB (2018) Lichen diversity of Udala CD area in Mayurbhanj district of Odisha, India. Abstract presented in International Conference on Plants and Environmental Pollution- 6, Lucknow. 
Pradhan S, Behera, PK, Pradhan S (2020) Revisionary Study on the Lichens Diversity of Khandagiri and Udayagiri. Indian Journal of Natural Sciences 10 (60): 26606-26612.

Pradhan S, Satapathy KB (2020) A Study on Diversity of Lichen in the North-West Transitional Zone of Mayurbhanj District of Odisha, India. Indian Journal of Natural Sciences 10 (61): 26985-26990.

Pradhan S, Upreti DK, Satapathy K (2021) Lichen Diversity on Shorea robusta Gaertn. in the Transitional Zone of Similipal Biosphere Reserve. Ambient Science 8 (2): 1-5.

Rout J, Das P, Upreti DK (2010) Epiphytic lichen diversity in a Reserve Forest in southern Assam, northeast India. Tropical Ecology 51(2):281.

Sahoo A, Pradhan S (2020) A Study on Diversity of Lichen in Jashipur and its Adjoining Area of Mayurbhanj, Odisha, India. Indian Journal of Natural Sciences10 (60): 20184-20188.

Satapathy KB, Nayak SK, Mishra R, Matwal S, Chand PK (2016) A greenery audit report on Utkal University campus, Vani Vihar, Bhubaneswar. A Floristic Inventory, UGC-HRDC, Utkal University, Bhubaneswar 1 (1): 1-236.

Sharma AK (2005) Text book of correlations and regression. Discovery Publishing House, New Delhi Pp. 1-212.

Shukla V, Upreti DK, Bajpai R (2014) Lichen diversity in different lichenogeographical regions of India. In Lichens to Biomonitor the
Environment. Springer, New Delhi. Pp.61-96.

Singh KP, Kamal K (2012) A note on the lichens from Similipal Biosphere Reserve. Indian Journal of Forestry 35(3): 383-390.

Sinha GP, Nayaka S, Joseph S (2018) Additions to the checklist of Indian lichens after 2010. Cryptogam biodiversity and assessment special Pp. 197-206.

Stevens GN (1979) Distribution and related ecology of macrolichens on mangroves on the east Australian coast. The lichenologist 11(3):293-305.

Suárez-Mota ME, Villaseñor JL, López-Mata L (2015) Ecological niche similarity between congeneric Mexican plant species. Plant Ecology and Evolution 148(3):318-328.

Swarnalatha G (2017) Macrolichen diversity of Mahendragiri hills of Odisha State, India. Plant Science Research 39(1):56-58.

Upreti DK (1996) Lichens on Shorea robusta in Jharsuguda district, Orissa, India. Flora and Fauna 2(2):159.

Weerakoon G, Aptroot A (2016) Nine new lichen species and 64 new records from Sri Lanka. Phytotaxa 280(2):152-162.

Wolseley P, Sanderson N, Thüs H, Carpenter D, Eggleton P (2017) Patterns and drivers of lichen species composition in a NWEuropean lowland deciduous woodland complex. Biodiversity and Conservation 26(2):401-19. 